\title{
HCK wt Allele
}

National Cancer Institute

\section{Source}

National Cancer Institute. HCK wt Allele. NCI Thesaurus. Code C51078.

Human HCK wild-type allele is located within $20 \mathrm{q} 11-\mathrm{q} 12$ and is approximately $50 \mathrm{~kb}$ in length. This allele, which encodes tyrosine-protein kinase HCK protein, is involved in signal transduction. 